\title{
Accessibility of people with disabilities to higher education: social attitudes of students and professors of a higher education institution
}

\author{
Jane Assunção Brunhara ${ }^{1}$ \\ https://orcid.org/0000-0003-3739-2418 \\ Ana Paula Berberian' \\ https://orcid.org/0000-0001-7176-7610 \\ Ana Cristina Guarinello ${ }^{1}$ \\ https://orcid.org/0000-0002-6954-8811 \\ Angela Regina Biscouto ${ }^{1}$ \\ https://orcid.org/0000-0001-9875-5142 \\ Simone Krüger $^{1}$ \\ https://orcid.org/0000-0002-3324-0698 \\ Daniel Vieira da Silva ${ }^{2}$ \\ https://orcid.org/0000-0002-9311-3703 \\ Josiane Bernart da Silva Ferla1,3 \\ https://orcid.org/0000-0003-4267-2553
}

Universidade Tuiuti do Paraná, Curitiba, Paraná, Brasil.

2 Universidade Estadual do Centro-0este Irati, Curitiba, Paraná, Brasil.

3 Instituto Federal do Paraná, Curitiba, Paraná, Brasil.

Research support source: Education Observatory Scholarship/Capes - Proc. 23038.002628/2013-41

Conflict of interests: Nonexistent

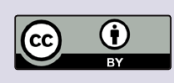

Received on: October 21, 2018 Accepted on: April 09, 2019

Corresponding address:

Josiane Bernart da Silva Ferla

Rua Assis Figueiredo, 1315, apto 91 ,

Torre $6 \mathrm{~A}$

CEP: 80630-280 - Curitiba - Paraná -

Brasil

E-mail: josiane.ferla@ifpr.edu.br

\section{ABSTRACT}

Purpose: to compare and analyze social attitudes of students and professors of a higher education institution about the inclusion of people with disabilities according to variables gender, age and areas of knowledge of participants.

Methods: the quantitative study was conducted on 601 academics, 583 being students and 18 university professors from a private university, who have contact with individuals with disabilities in the classroom. A questionnaire was applied to identify the social attitudes related to the variables correlated above.

Results: the sample included $97 \%$ of students, 417 being females and 184 males. Nearly $43 \%$ were younger than 20 years and $6 \%$ older than 40 years. The female professors and students had higher agreement with the questionnaire, while male professors and students reported lower satisfaction. Concerning age, the younger individuals were the most dissatisfied ones. In relation to the field of knowledge, the Exact, Human and Health Sciences, in this order, presented increased agreement with the research instrument.

Conclusion: the study investigated the social attitudes of professors and students about the inclusion of people with disabilities, analyzing the results according to gender, age and area of knowledge, comparing and correlating with the agreement about the questionnaire. The results revealed the need to deepen the studies about variables that may influence the social attitudes related to the inclusion and permanence of these individuals in higher education institutions.

Keywords: Education, Higher; Mainstreaming (Education); Disabled Persons 


\section{INTRODUCTION}

Currently, in Brazil, there has been an increase in the access to Higher Education (HE), has observed by the significant increase in the number of students entering public and private graduation courses and other modalities of higher education in the last decades ${ }^{1}$. This is the result of public policies and programs established after the 1990s, by initiatives coordinated by social movements committed with fundamental rights ${ }^{2}$.

Combined to this expansion, several challenges should be overcome to allow the effective democratization of this educational level. These challenges include the presence, inside the Higher Education Institutions (HEI), of students with different and unequal economic, educational and cultural conditions $^{2}$. Among these students, there are individuals with disabilities, whose increased access to the $\mathrm{HEl}$ raised the need to promote discussions about educational policies and proposals based on the paradigm of school and social inclusion ${ }^{2,3}$.

Therefore, as a result of movements to protect the expansion and democratization of Higher Education $(\mathrm{HE})$, ongoing since the end of the $20^{\text {th }}$ century, after the 2000s specific programs were created in Brazil to reduce the obstacles faced by minority groups, who previously had no access to $\mathrm{HE}^{2}$. These programs include the FIES - Student Financing Fund ${ }^{4}$ and PROUNI - Program University for All ${ }^{5}$, which aim to expand the access to private $\mathrm{HEl}$, by studies financing and granting of scholarships ${ }^{2}$. Other strategy that is part of actions targeted to students with disabilities in the HE was the creation of a reservation system, in the so-called quotas ${ }^{6}$.

However, even though the number of such students enrolled in HE has been increasing every year ${ }^{1}$, this does not assure their permanence in the HEI, and even less a high-quality education ${ }^{7}$. Thus, despite the advances in the establishment of measures and actions to expand the entrance of these students with disabilities in the HE, different barriers have restricted the possibilities of their active participation in the academic training process. These barriers may be physical, communicative, methodological, among others $^{8}$, and this study will focus on the attitudinal barriers, specifically concerning the social attitudes.

It should be highlighted that attitudinal barriers are those related to the attitudes of people toward individuals with disabilities, due to lack of information and prejudice, which causes discrimination, more prejudice and consequently the exclusion'. The social attitudes are predispositions to behaviors in certain situations, originated from values internalized during the development of each individual? ${ }^{7}$.

The recognition of such barriers, either attitudinal or environmental, is the first step to promote the autonomy and citizenship $p^{2,9,10-12}$. According to the author, segregation attitudes related to differences between people should be overcome, since these differences characterize the singularity of each person in society.

Therefore, it may be stated that the commitment with the analysis of manifestations of attitudinal barriers, as well as their implications, is fundamental, since they may be identified as determinants of a significant number of dropouts, enrollment cancellations and problems in the academic performance of individuals self-acknowledged as disabled ${ }^{7}$.

Therefore, this study investigated the social attitudes of people from the academic environment in relation to the accessibility of individuals with disabilities to HE, as one of the aspects related to the attitudinal barriers.

\section{METHODS}

Data collected for the present study followed the ethical guidelines recommended for investigations on human beings and was approved by the Institutional Review Board of University Tuiuti do Paraná under $\mathrm{n}$. 0782/2013.

The present quantitative study was conducted on a private $\mathrm{HEl}$, from a city in Southern Brazil. The inclusion and exclusion criteria were established for a population of students and professors who had contact with students with disabilities in the classroom. In summary, the study included all professors and students who, regardless of their field of knowledge or academic period, had daily contact with students with disabilities and accepted to participate in the study. Concerning the exclusion criteria, the study did not include individuals who did not have contact with individuals with disabilities in the daily life in the classroom. The study was conducted on 583 students and 18 professors from 12 graduation courses of areas of knowledge of Human (7), Health (13) and Exact (2) sciences, adding up to 601 participants.

For sample selection, a previous survey was performed on the Inclusive Education Commission of the HEI on the first semester of 2017, to identify the classrooms that had students self-acknowledged with some type of disability. After checking the courses in which these students were inserted, the coordinators of these courses were directly contacted, and a 
presentation letter was sent to obtain authorization for the study. After this authorization, the date and time were arranged for application of a questionnaire in the classrooms of students with disabilities, together with the professors and other students who accepted to participate in the study.

Considering the nature and relevance of shared investigation, and highlighting the volunteer character, the participants who spontaneously accepted to participate signed an informed consent form (Resolution CNS 466/2012) and received the questionnaire ELASI Likert Scale of Social Attitudes Related to Inclusion. The average duration of questionnaire application was 20 to 30 minutes, in the presence of the investigator, to allow the elucidation of occasional doubts during the study. Data were collected in the academic environment between April and August 2017, in graduation courses from Human, Health and Exact Sciences.

The research instrument applied was a questionnaire entitled ELASI - Likert Scale of Social Attitudes Related to Inclusion. The ELASI is a Likert scale with 5 alternatives. The goal of this instrument is to measure the social attitudes related to inclusion, and it was created, validated and standardized by the research group Difference, Depreciation and Stigma, from the Department of Special Education of the Philosophy and Sciences College of UNESP - Marília ${ }^{13}$.

This questionnaire is composed of 35 items, being 30 related to the measurement of social attitudes in relation to inclusion, and 5 items compose the "lie scale", which includes predictable questions, allowing to assess the reliability and seriousness with which the participant responded to the questionnaire.

It should be highlighted that part of the items in the social attitudes scale is positive, i.e. its questions are proposed to express social attitudes considered favorable for inclusion by those who agree, while others are composed of negative items, which express social attitudes favorable to inclusion by those who disagree with them. Therefore, each item in the questionnaire includes a positive or negative question related to inclusion, followed by 5 alternatives, namely: I fully agree; I partly agree; I do not agree nor disagree; I partly disagree; I fully disagree. Thus, the alternatives express different degrees of agreement or disagreement in relation to the question, yielding an individual score. Therefore, values were assigned to the items, depending on the alternative indicated, according to the following criterion: in positive items, score 5 is assigned to the "fully agree" alternative, score 4 to "partly agree", and so on, until score 1 for "fully disagree". In negative items the scores are assigned in an inverted manner, with maximum score assigned to the "fully disagree" alternative and minimum score to the "fully agree" alternative.

The total score of the respondent it represented by the sum of scores obtained in the items, which may thus vary within the range 30 to 150 points. The higher the score, the more favorable the social attitudes in relation to the inclusion and permanence of the student with disability. The inverse relationship was also considered, i.e. the lower the score, the less favorable the social attitudes of the respondent in relation to the inclusion and permanence of the student with disability.

The scores of the questionnaire ELASI (Type A) were analyzed on the Software Statistica 13.2. Initially the normality test was applied to the final scores, by the Shapiro-Wilk test, at a significance level of 0.05 (5\%), yielding values $p<0.05$, i.e. rejecting the normality hypothesis. Therefore, the analysis was performed by non-parametric tests (Mann-Whitney and ANOVA Kruskal-Wallis test). 


\section{RESULTS}

This section presents the grouped results, shown in Tables 1 to 7 .

Table 1. Sample distribution and analysis according to gender

\begin{tabular}{cccccc}
\hline GENDER & FREQUENCY & $\%$ & $\begin{array}{c}\text { VARIATION } \\
\text { MIN.-MAX. }\end{array}$ & MEDIAN & $\begin{array}{c}\text { SCATTER } \\
\mathbf{Q}_{1}-\mathbf{Q}_{3}\end{array}$ \\
\hline Females & 417 & 69 & $90-150$ & 134.0 & $128.0-139.0$ \\
Males & 184 & 31 & $55-150$ & 131.5 & $122.0-138.0$ \\
\hline
\end{tabular}

Source: study data

* Legend: (\%): Percentage; (MIN): Minimum; (MAX): Maximum; (Q1): Quartile 1; (Q3): Quartile 3.

It should be mentioned that, in the Tables, the public is composed of 601 individuals, being 583 students and 18 professors, both males and females, in units of people.

Table 2. Sample distribution and analysis according to age

\begin{tabular}{cccccc}
\hline AGE & FREQUENCY & $\%$ & $\begin{array}{c}\text { VARIATION } \\
\text { MIN.-MAX. }\end{array}$ & MEDIAN & $\begin{array}{c}\text { SCATTER } \\
\mathbf{Q}_{1}-\mathbf{Q}_{3}\end{array}$ \\
\hline Up to 20 years & 261 & 43 & $90-148$ & 132.0 & $122.0-138.0$ \\
21 to 30 years & 241 & 40 & $55-149$ & 134.0 & $128.0-139.0$ \\
31 to 40 years & 64 & 11 & $77-150$ & 134.0 & $130.0-139.0$ \\
Above 40 years & 35 & 6 & $113-150$ & 137.0 & $133.0-141.0$ \\
\hline
\end{tabular}

Source: study data

* Legend: (\%): Percentage; (MIN): Minimum; (MAX): Maximum; (Q1): Quartile 1; (Q3): Quartile 3.

Considering the score intervals of each questionnaire, varying from 30 to 150 points, the variation (maximum and minimum values), median and scatter (quartile 1 and quartile 3 values, called Q1 and
Q3, respectively) are presented in pure numbers, i.e. in non-dimensional form, while the frequency of people is also expressed in percentages.

Table 3. Sample distribution and analysis according to area of knowledge

\begin{tabular}{cccccc}
\hline AREA & FREQUENCY & $\%$ & $\begin{array}{c}\text { VARIATION } \\
\text { MIN.-MAX. }\end{array}$ & MEDIAN & $\begin{array}{c}\text { SCATTER } \\
\mathbf{Q}_{1}-\mathbf{Q}_{3}\end{array}$ \\
\hline Human Sciences & 117 & 19 & $102-149$ & 133.0 & $127.0-139.0$ \\
Health Sciences & 436 & 73 & $55-150$ & 134.0 & $126.0-139.0$ \\
Exact Sciences & 48 & 8 & $99-147$ & 131.5 & $119.0-138.0$ \\
\hline
\end{tabular}

Source: study data

* Legend: (\%): Percentage; (MIN): Minimum; (MAX): Maximum; (Q1): Quartile 1; (Q3): Quartile 3. 
It should be considered that this sample is distributed among Human, Health, and Exact sciences.

Table 4. Sample distribution and analysis according to public

\begin{tabular}{cccccc}
\hline PUBLIC & FREQUENCY & $\%$ & $\begin{array}{c}\text { VARIATION } \\
\text { MIN.-MAX. }\end{array}$ & MEDIAN & $\begin{array}{c}\text { SCATTER } \\
\mathbf{Q}_{1}-\mathbf{Q}_{3}\end{array}$ \\
\hline General & 601 & $97 \%$ & $55-150$ & 134.0 & $126.0-139.0$ \\
Students & 583 & $3 \%$ & $55-150$ & 133.0 & $126.0-139.0$ \\
Professors & 18 & $\%$ & $113-146$ & 140.0 & $135.0-144.0$ \\
\hline
\end{tabular}

Source: study data

* Legend: (\%): Percentage; (MIN): Minimum; (MAX): Maximum; (Q1): Quartile 1; (Q3): Quartile 3.

Finally, the ages were asked and assigned to the questionnaires, without restriction, yet with utilization of this variable. Additionally, the other related variables were public, gender, ages and areas of knowledge.

Table 5. Result of analyses, according to public, by gender

\begin{tabular}{ccccc}
\hline PUBLIC AND GENDER & N & $\begin{array}{c}\text { VARIATION } \\
\text { MIN.-MAX. }\end{array}$ & MEDIAN & $\begin{array}{c}\text { SCATTER } \\
\mathbf{Q}_{1}-\mathbf{Q}_{3}\end{array}$ \\
\hline Students & & & & \\
Females & 407 & $90-150$ & 134.0 & $128.0-139.0$ \\
Males & 176 & $55-150$ & 131.0 & $121.5-138.0$ \\
\hline Professors & 10 & $128-146$ & 141.0 & $134.0-144.0$ \\
Females & 8 & $113-146$ & 139.0 & $136.5-142.5$ \\
Males & & & & \\
\hline
\end{tabular}

Source: study data

* Legend: (\%): Percentage; (MIN): Minimum; (MAX): Maximum; (Q1): Quartile 1; (Q3): Quartile 3.

Also, in relation to the tables, it should be noted that the sample of this study included 601 participants, including $583(97 \%)$ students and $18(3 \%)$ professors.
Among these, 417 (69\%) were females and 184 (31\%) were males.

Table 6. Result of analyses, according to public, by age

\begin{tabular}{ccccc}
\hline PUBLIC AND AGE & N & $\begin{array}{c}\text { VARIATION } \\
\text { MIN.-MAX. }\end{array}$ & MEDIAN & $\begin{array}{c}\text { SCATTER } \\
\mathbf{Q}_{1}-\mathbf{Q}_{3}\end{array}$ \\
\hline $\begin{array}{c}\text { Students } \\
\text { Up to 20 years }\end{array}$ & 261 & $90-148$ & 132.0 & $122.0-138.0$ \\
21 to 30 years & 241 & $55-149$ & 134.0 & $128.0-139.0$ \\
31 to 40 years & 54 & $77-150$ & 133.0 & $130.0-138.0$ \\
Above 40 years & 27 & $121-150$ & 136.0 & $133.0-140.0$ \\
\hline Professors & & & & \\
31 to 40 years & 10 & $128-144$ & 136.5 & $134.0-141.0$ \\
Above 40 years & 8 & $113-146$ & 143.0 & $139.0-146.0$ \\
\hline
\end{tabular}

Source: study data

* Legend: (\%): Percentage; (MIN): Minimum; (MAX): Maximum; (Q1): Quartile 1; (Q3): Quartile 3. 
Concerning the sample distribution according to age, $261(43 \%)$ participants in the age range up to 20 years, $241(40 \%)$ aged 21 to 30 years, 64 (11\%) between 31 and 40 years and 35 (6\%) above 40 years.
Concerning the field of knowledge, the following distributions were calculated: Health - 436 (73\%); Human - 117 (19\%); Exact - 48 (8\%).

Table 7. Result of analyses, according to public, by area of knowledge

\begin{tabular}{ccccc}
\hline $\begin{array}{c}\text { PUBLIC AND AREA OF } \\
\text { KNOWLEDGE }\end{array}$ & $\mathbf{N}$ & $\begin{array}{c}\text { VARIATION } \\
\text { MIN.-MAX. }\end{array}$ & MEDIAN & $\begin{array}{c}\text { SCATTER } \\
\mathbf{Q}_{1}-\mathbf{Q}_{3}\end{array}$ \\
\hline Students & 112 & $102-149$ & 133.0 & $125.0-139.0$ \\
Human Sciences & 426 & $55-150$ & 134.0 & $126.0-139.0$ \\
Health Sciences & 45 & $99-147$ & 131.0 & $121.0-138.0$ \\
Exact Sciences & 5 & $128-144$ & 138.0 & $131.0-141.0$ \\
\hline Professors & 10 & $135-146$ & 142.0 & $138.0-146.0$ \\
Human Sciences & 3 & $113-140$ & 134.0 & $113.0-140.0$ \\
Health Sciences & & & \\
Exact Sciences & & & & \\
\hline
\end{tabular}

Source: study data

* Legend: (\%): Percentage; (MIN): Minimum; (MAX): Maximum; (Q1): Quartile 1; (Q3): Quartile 3.

\section{DISCUSSION}

Concerning the public, the results were compared between students and professors by the Mann-Whitney test, at a significance level of $0.05(5 \%)$, with $p=$ 0.0016 . Therefore, there was significant difference between scores for these groups, with significantly higher scores for the professors, i.e. more favorable social attitudes in relation to inclusion than the students. Table 1, concerning gender, and comparing the results of students and professors by the same test and significance level, revealed $p=0.0026$. Thus, there was significant difference between scores for both genders, with significantly higher result for the females, evidencing that females are more favorable for inclusion than males.

Considering age, as shown in Table 2, comparison of the results of students and professors by the ANOVA Kruskal-Wallis test, at a significance level of 0.05 (5\%), with $p=0.0006$, evidenced significant difference in the outcomes between ages. By the multiple comparisons test, differences were identified between ages up to 20 years, 21 to 30 years $(p=0.0456)$, and ages up to 20 years compared to above 40 years $(p=0.0023)$. Therefore, the results for ages up to 20 years presented significantly lower results, i.e. more unfavorable in relation to inclusion.

Comparison between areas of knowledge, displayed in Tables 3 and 4 , for students and professors, by the ANOVA Kruskal-Wallis test, at a significance level of $0.05(5 \%)$, revealed $p=0.2472$, i.e. without significant difference in outcomes concerning the inclusion between areas of knowledge. According to the public, by area of knowledge, comparison of the results between students and professors by the ANOVA Kruskal-Wallis test, at a significance level of $0.05 \%$ $(5 \%)$, revealed Student (courses), $p=0.3587$ (without significant difference) and Professors (courses), $p=$ 0.1809 (without significant difference). Therefore, there is no significant difference in outcomes concerning the inclusion between areas of knowledge, considering students and professors. According to the results, a significant part of individuals presents favorable attitudes, i.e. positive, in relation to the inclusion of students with disabilities in the $\mathrm{HE}$, as observed by the median score of 134 , according to the general public.

Also, according to the Mann-Whitney test at a significance level of 0.05 (5\%), as shown in Table 5, the results of students (Females $x$ Males) revealed $p=$ $0.0012^{*}$ (significant difference), while for the professors (Females $x$ Males) the result was $p=0.8590$ (without significant difference). Therefore, among students, there was a significant difference between genders, with significantly higher result for the females for the total scores, i.e., more favorable for inclusion compared to males. No significant difference between genders was observed for the professors.

Concerning the results according to the public, by age, in Table 6, comparison of students and professors 
by the ANOVA Kruskal-Wallis test at a significance level of $0.05(5 \%)$, the Students (age) presented $p=0.0340$ * (significant difference only between students aged up to 20 years and 21 to 30 years) and Professors (ages) presented $p=0.1679$ (without significant difference). Thus, for students aged up to 20 years, the differences are significantly inferior, i.e. more unfavorable in relation to inclusion, concerning the students aged 21 to 30 years. For the professors, significant differences were not observed between ages.

It was also observed that the responses provided by Students and Professors did not vary according to the area of knowledge, i.e. between Human, Health and Exact sciences, as shown in Table 7. Different from these results, other study indicated that the area of training may have significant relation with the social attitudes toward inclusion ${ }^{14}$. Therefore, both the option for a certain area may be influenced by the previous social attitudes, and also the knowledge and experiences acquired in an area may change the social attitudes ${ }^{14}$.

Considering the values of scores that revealed predominance of favorable attitudes for inclusion, it may be assumed that this may be related to the presence and functioning of an Inclusive Education Committee, established since 2002 in this $\mathrm{HEI}^{15}$. This Commission includes the participation of two individuals with disability, who actively participate in programs directed to accessibility, promoting events such as lectures for students, professors and employees of the academic community. Additionally, the institution has several employees with disabilities who directly relate to the entire academic Community, in different spaces, such as the library, administrative sectors and training clinics.

Concerning the actions of the institution to favor the access of individuals with disabilities to the HE, it should also be mentioned that the facilities of this institution are well adapted to individuals with disabilities, including elevators in all buildings, ramps, adapted toilets, besides podotactile floors and high-relief strips fixated on the floor to aid the movement of people with visual impairment. Additionally, the social living in different contexts of the HEI, with the 22 students self-acknowledged as having some type of disability (intellectual, visual, physical or hearing), may promote experiences to allow the academic community to recognize the right and potentials of these students ${ }^{16}$.

If there is a tendency of participants to present favorable social attitudes for the inclusion of people with disabilities in the HE, the present results indicate significant difference between the scores of students and professors, since the professors presented more favorable responses to these attitudes. The professors' experience would be an important variable for the social attitudes toward students with disability, since along the years the possibility of contact with students with several conditions, including different needs and potentials related to learning, may lead to more favorable opinions in relation to the educational inclusion ${ }^{16}$. Other aspect that had positive impact on the responses provided by the participants, in general (Professors and Students), refers to the variable gender, since the scores were significantly favorable for the females. National and international authors indicate that the females tend to have more favorable attitudes toward inclusion ${ }^{17-20}$. Based on these results, the fact that the females are culturally guided to caring tasks may influence the more favorable social attitudes in relation to inclusion. It should be emphasized that, in contemporary societies, there is a tendency of assigning women to tasks of caring for people and solving conflicts, in both public and private spaces ${ }^{21}$. However, concerning the impact of the variable gender, when the scores were compared between Students and Professors, it was observed that female students presented more favorable attitudes for inclusion, while for the professors there was no significant difference between genders.

In relation to the results achieved, considering the age of participants, significantly lower results were observed in the social attitudes related to inclusion in the HE for ages up to 20 years. To analyze these results, it may be considered that these students still did not have sufficient experiences with interpersonal relations, in both quantity and quality, with people with some type of disability.

Other important aspect to be considered is that the inclusion of people with disabilities in the Brazilian educational system, and in regular schools, has been more effectively performed after $2007^{22}$. Finally, the establishment and impact of educational policies are still recent, which favored the significant growth of enrollment of students with disabilities in basic education, namely 85\% between 2003 and 2015, according to the School Census of MEC/INEP22. Thus, it may be inferred that several students who arrive to the $\mathrm{HE}$, aged up to 20 years, still did not participate in an inclusive school, which might influence their less 
favorable social attitudes concerning the students with disabilities.

It should be highlighted that this initial hypothesis appears in other studies, even though, as in the present study, it is not necessarily confirmed at study completion. Regarding the social attitudes of professors inserted in municipal fundamental schools, with specialization in different fields of education, disagreeing with the initial hypothesis of the authors, indicates that the fact that a group of professors is specialized in Special Education had no significant effect on the social attitudes of participants ${ }^{23}$. For this study, the training of professors for inclusive education should promote a change in the concept toward the student with disability that might lead to truly inclusive attitudes, not prioritizing the contents and knowledge specific to the disabilitieds ${ }^{16}$.

The areas of knowledge of graduation courses should be considered in the social attitudes related to inclusion in the HE, since it considers that training in human sciences may influence more positive social attitudes toward inclusion ${ }^{24}$. Based on a study that aimed to verify the differences in social attitudes between students of 7 graduation and post graduation courses of a HEl, comparing the social attitudes of students in relation to inclusion between all courses surveyed, significant differences were observed in the responses provided by MSc students in Psychology, Health sciences, compared to students of Environmental Sciences, Library Sciences and Computing ${ }^{24}$. Thus, it is suggested that the more positive results observed for MSc students in Psychology may be related to the presence of a student with disability in the classroom, and the issues of accessibility and inclusion are part of the contents addressed in this field.

The present results revealed that different cultural and social factors, also related to the life experiences, may influence the social attitudes. These attitudes may be learned and thus they may be changed, and the essentially characteristic determinants of social attitudes are cognitive (beliefs and opinions), affective (in favor of or against the attitudinal object) and behavioral (with predisposition to action, being a combination of the two former aspects, and that lead to a certain behavior $)^{25}$. Usually, there is agreement between these three components, and when there is a change in one of them, there are processes to restore this agreement, leading to an attitudinal reorganization.

Any change in some of these three components may change the others, since the entire system is triggered when one component is altered. Consequently, a new information, new experience, or new behavior adopted to meet the social norms or when facing another type of agent that may lead to such behavior, may create a state of unconsciousness between the three attitudinal components, leading to a change in attitude ${ }^{25}$.

Therefore, it may be stated that attitudinal changes in relation to inclusion are possible, in the context of education. Considering that the social attitudes are constituted along the history of people, in a social, economic and cultural scenario, they may be learned and modified. Therefore, it seems possible to state that the social living with students with disabilities may lead to the promotion of changes to more positive social attitudes in relation to inclusion. Another important aspect for these changes would be the development of institutional actions to evidence the needs of students with disabilities and contribute to meet their physical, pedagogical and communicative needs, among others. Other aspect to be considered concerns the training of professors, who should be prepared to work with students with disabilities and promote a culture of inclusion in the classroom. The importance of debates and discussions on this issue involving the entire academic community is highlighted, as well as the insertion of this issue in the curricula of all courses. Therefore, it is importance to have solid accessibility sectors in the $\mathrm{HEl}$, acting with the entire academic community.

\section{CONCLUSION}

The present results demonstrated that a significant part of participants was favorable for the inclusion of students with disabilities in the HE. This may be related to some factors; the institution where the study was conducted promotes actions with the academic community, by an Inclusive Education Committee, whose characteristics are related to the inclusive context, as described above. It was also possible to notice, in the present results, significant differences in scores between populations concerning the public (Students and Professors), gender and age, with females being more favorable to inclusion than males.

It should be emphasized that the utilization of ELASI as an instrument that allows the survey of quantitative data allows the identification of tendencies in relation to the positions assumed by the participants. Therefore, these results, which in general were favorable for the inclusion, not necessarily assure that the interpersonal relations of each student with disability are positive 
during their academic life. Living significantly with the singularity is the outcome of continuous elaboration. In this sense, the present results may express an important space to be filled by the mainstreaming Committee, to promote actions aiming to expand the community awareness for aspects related to diversity.

Thus, qualitative studies are important to deepen the analysis of this reality, using instruments that allow the access to different experiences about the accessibility and permanence of students with disabilities in the HE.

Finally, besides the encouragement of studies about the social attitudes related to the accessibility and permanence of students with disabilities in the $\mathrm{HE}$, it is paramount to highlight the fundamental role of institutional actions that may promote an inclusive environment in the university community.

\section{REFERENCES}

1. INEP. Instituto Nacional de Estudos e Pesquisas Anísio Teixeira. Sinopse Estatística da Educação Superior 2015. Brasília: INEP, 2016. Disponível em: http://portal.inep.gov.br/ basica-censo-escolar-sinopse-sinopse.

2. Castro SF, Almeida MA. Ingresso e permanência de alunos com deficiência em universidades públicas brasileiras. Ensino Superior e Deficiência. Rev. Bras. de Educ. Especial. [periódico na Internet] 2014 [acesso em 20 de setembro de 2017];20(2):[aproximadamente 16 p.]. Disponível em: http://www.scielo.br/pdf/rbee/ v20n2/03.pdf.

3. Silva HM, Souza SM, Prado F, Ribeiro AL, Lia C, Carvalho EL. Inclusão de estudantes no ensino superior: revisão de literatura. Rev. Univers. Vale Rio Verde. [periódico na Internet] 2012 [acesso em 15 de outubro de 2017];10(2):[aproximadamente 11 p.]. Disponível em: http://periodicos.unincor.br/ index. php/revistaunincor/article/view/722/pdf.

4. Brasil. Congresso Nacional. Lei no 10.260, de 12 de julho de 2001. Dispõe sobre o fundo de financiamento ao estudante do ensino superior e dá outras providências - FIES. Diário Oficial da União, Brasília, DF, 13 jul. 2001. Disponível em: http:// www.planalto.gov.br/ccivil_03/leis/LEIS_2001/ L10260.htm.

5. Brasil. Lei no. 11.096 , de 13 de janeiro de 2005a. Institui o Programa Universidade para Todos - PROUNI, regula a atuação de entidades beneficentes de assistência social no ensino superior; Diário Oficial da União, Brasília, DF, 14 jan. 2005. Disponível em: http://www.planalto.gov. br/ccivil_03/_ato2004-2006/2005/lei/L11096.htm.

6. Brasil. Lei no. 13.409 , de 28 de dezembro de 2016b. Altera a Lei No. 12.711, de 29 de agosto de 2012, para dispor sobre a reserva de vagas para pessoas com deficiência nos cursos técnico de nível médio e superior das instituições federais de ensino. Diário Oficial da União, Brasília, DF, 28 dez. 2016b. Disponível em: http://www.planalto.gov.br/ ccivil_03/_ato2015-2018/2016/lei/L1340.

7. Omote $\mathrm{S}$. Atitudes em relação à inclusão no ensino superior. JORSEN [periódico na Internet]. 2016 [acesso em 25 de março de 2017];16(1):[aproximadamente $4 \quad$ p.]. Disponível em: https://onlinelibrary.wiley.com/doi/ epdf/10.1111/1471-3802.12283.

8. Sassaki RK. Inclusão: o paradigma do século 21. Rev. de Educ. Esp. [periódico na Internet]. 2005 [acesso em 01 de outubro de 2017];1(1):[aproximadamente 4 p.]. Disponível em http://portal.mec.gov.br/seesp/arquivos/pdf/ revistainclusao1.pdf.

9. Castro SF, Almeida MA. Ingresso e permanência de alunos com deficiência em universidades públicas brasileiras. Rev. Bras. Educ. Esp. [periódico na Internet]. 2014 [acesso em 10 de setembro de 2017];20(2):[aproximadamente 15 p.]. Disponível em: http://www.scielo.br/scielo.php?pid=S1413$65382014000200003 \&$ script $=$ sci_abstract\&tlng $=$ pt.

10. Bíssigo MCK. As políticas públicas para a construção de uma sociedade inclusiva: conquistas e desafios a partir dos movimentos sociais. ScientiaTec. [periódico na Internet]. 2016 [acesso em 30 de outubro de 2017];3(2): [aproximadamente 12 p.]. Disponível em: https://periodicos.ifrs.edu.br/ index.php/ScientiaTec/article/download/1581/1349.

11. Bisol CA, Valentini CB, Simioni JL, Zanchin J. Estudantes surdos no ensino superior: reflexões sobre a inclusão. Cad. de Pesq. [periódico na internet]. 2010 [acesso em 25 de setembro de 2017];40(139):[aproximadamente 25 p.]. Disponível em: http://www.scielo.br/pdf/cp/ v40n139/v40n139a08.

12. Santana ES. Atitudes de estudantes universitários frente a alunos com deficiência na UNESP de Presidente Prudente [Tese] Marilia (SP): Universidade Estadual Paulista, Faculdade de Filosofia e Ciências; 2013. Disponível em: https:// www.marilia.unesp.br/Home/Pos-Graduacao/ Educacao/Dissertacoes/santana_es_do_mar.pdf. 
13. Omote S. A construção de uma escala de atitudes sociais em relação à inclusão: notas preliminares. Rev. Bras. de Educ. Esp. [periódico na Internet]. 2005 [acesso em 25 de março de 2017];11(1):[aproximadamente 34 p.]. Disponível em: http://www.abpee. net/homepageabpee04_06/artigos_em_pdf/ revista11 numero1pdf/3sadaoomote.pdf.

14. Omote $\mathrm{S}$. Atitudes sociais em relação à inclusão: estudos brasileiros. Rev. Ibero-Americana de Est. em Educ. [periódico na Internet]. 2013 [acesso em 20 de setembro de 2017];8(3):[aproximadamente 10 p.]. Disponível em: https://periodicos.fclar.unesp. br/iberoamericana/article/viewFile/6586/4843.

15. Berberian AP, Krüger SI, Miranda BA, Guarinello AC, Costa LV, Silva DVF et al. Inclusão de alunos com deficiência em uma Universidade particular de Curitiba. Rev. Disturb. Comun. [periódico na Internet]. 2017 [acesso em 10 de outubro de 2017;29(4):[aproximadamente 9 p.]. Disponível em: https://revistas.pucsp.br/index.php/dic/article/ view/32883.

16. Gai DN, Naujorks MI. Inclusão: contribuições da teoria sócio interacionista à inclusão escolar de pessoas com deficiência. Rev. Educ. [periódico na Internet]. 2006 [acesso em 11 de outubro de 2017];31(2):[aproximadamente 15 p.]. Disponível em: https://periodicos.ufsm.br/reveducacao/article/ download/1577/877.

17. Fonseca-Janes CRX, Omote $\mathrm{S}$. Atitudes sociais em relação à inclusão: o curso de Pedagogia da Faculdade de Ciências e Tecnologia da UNESP. Nuances: Est. sobre Educ. [periódico na Internet]. 2013 [acesso em 3 de outubro de 2017];24(2):[aproximadamente 15 p.]. Disponível em: http://revista.fct.unesp.br/index.php/Nuances/ article/view/2486.

18. Pearman E, Barnhar M, Huang A, Mellblom C. Educating all students in school: attitudes and beliefs about inclusion. JSTOR: Education and Training in Mental Retardation [serial on the Internet]. 1992 [cited 2017 Oct 17];27(2):[about 6 p.]. Available from: http://www.jstor.org/ stable/23878685?seq=1\#page_scan_tab_contents.

19. Avramidis E, Bayliss P, Burden R. Student teacher' attitudes towards the inclusion of children with special educational needs in the ordinary school. Teaching and Teacher Education [serial on the Internet]. 2000 [cited 2017 Oct 15];6(16):[about 16 p.]. Available from: https://eric. ed.gov/?id=EJ607365.

20. Gilberto FS, Marta N. Sentidos e significados da educação inclusiva: o que revelam os profissionais do Centro de Capacitação em Educação Inclusiva e Acessibilidade (CEIA/Canoas). Rev. Diálogo Educ. [periódico na Internet]. 2013 [acesso em 2 de setembro de 2017];13(39):[aproximadamente 21 p.]. Disponível em: https://periodicos. pucpr.br/index.php/dialogoeducacional/article/ view/8321/8078.

21. Santos SMM, Oliveira L. Igualdade nas relações de gênero na sociedade do capital: limites, contradições e avanços. Rev. Katálysis [periódico na Internet]. 2010 [acesso em 20 de outubro de 2017];13(1):[aproximadamente 8 p.]. Disponível em: http://www.scielo.br/pdf/rk/v13n1/02.pdf.

22. Brasil. A Consolidação da Inclusão Escolar no Brasil 2003 a 2016. Ministério da Educação. Secretaria de Educação Continuada, Alfabetização, Diversidade e Inclusão. Brasília, DF, 2016a.

23. Omote S, Pereira J, Antonio A. Atitudes sociais de professores de um município de médio porte do Paraná em relação à inclusão. Rev. Pesq. e Prát. Psicossociais [periódico na Internet]. 2011 [acesso em 01 de outubro de 2017];6(1):[aproximadamente 8 p.]. Disponível em: https://ufsj.edu.br/portal2repositorio/File/revistalapip/volume6_n1/Omote_\&_ Pereira_Junior.pdf.

24. Crochik JL, Freller CC, Dias MAL, Feffermann M, Nascimento RB, Casco R. Atitudes de professores em relação à educação inclusiva. Rev. Psicol., Ciên. e Profissão [periódico na Internet]. 2009 [acesso em 01 de outubro de 2017];29(1):40-59. Disponível em: http://www.scielo.br/pdf/pcp/v29n1/v29n1a05. pdf.

25. Nabuco ME. Práticas institucionais e inclusão escolar. Cadern. de Pesq. [periódico na Internet]. 2010 [acesso em 17 de outubro de 2017];40(139):[aproximadamente $11 \quad$ p.]. Disponível em: http://www.scielo.br/pdf/cp/ v40n139/v40n139a04.pdf. 